\title{
TRANSFORMASI EKONOMI ZAKAT: PENERIMA MENJADI WAJIB ZAKAT
}

\author{
Hamzah$^{1}$ dan St. Umrah ${ }^{2}$
}

\section{Abstrak}

Penelitian ini bertujuan untuk mengelaborasi pendayagunaan zakat dan pengembangan amil pada konsep kepemimpinan transformatif. Jenis penelitian yang digunakan adalah penelitian kepustakaan (library research). Sumber data penelitian ini terdiri dari 8 buku, 4 jurnal dan 8 situs internet yang terkait dengan informasi trasformasi ekonomi zakat. Data dianalisis menggunakan teknik analisis isi (content analysis). Hasil kajian menunjukkan bahwa amil memiliki peran startegis dalam trasfer of knowledge kepada penerima zakat dalam kaitanya melakukan pendayagunaan zakat sebagai penguatan masyarakat. Pandangan Schermerhor digunakan dalam pengembangan amil dalam mewujudkan kepemimpinan transformatif. Dampak dari model kepemimpinan trasformatif amil adalah dapat membalikkan penerima zakat menjadi pemberi zakat.

Kata Kunci: kepemimpinan, transformasi, ekonomi, zakat

\section{Abstract}

This research aims to elaborate the utilization of zakat and the development of amil in the concept of transformative leadership. The type of research used is library research. The data source in this study consists of 8 books, 4 journals and 8 internet sites related to information on zakat economic transformation. The method is using content analysis techniques to discuss results. The results of the study indicate that amil has a strategic role in the transfer of knowledge to the recipients of zakat in the context of making use of zakat as community empowerment. Schermerhor's view is used in the development of amil in realizing transformative leadership. The impact of the amil transformative leadership model can transform the mustahik of zakat into the muzakki of zakat.

Keywords: leadership, transformation, economics, zakat

\footnotetext{
${ }^{1}$ Fakutas Ekonomi dan Bisnis Islam (FEBI) UIN Alauddin Makassar, Email: hamzahkhaeriyah@yahoo.co.id ${ }^{2}$ Jurusan Syariah Sekolah Tinggi Agama Islam Negeri (STAIN) Sorong Email: umrah.hasankhaeriyah@gmail.com
} 


\section{A. PENDAHULUAN}

Sebagai bagian salah satu rukun Islam, zakat dimaksudkan untuk memberikan dampak peningkatan sosial ekonomi pada penerima zakat, (Hafidhuddin, 2002). Peningkatan sosial ekonomi outcome penerima zakat dilakukan dengan optimalisasi fungsi amil zakat sebagai agen pemegang otoritas pengelolaan zakat dalam agama Islam, (Hamzah, 2016). Amil zakat di Indonesai telah mengalami transformasi personal keinstitusional dengan penetapan badan amil zakat sebagai pemegang otoritas dalam pengelolaan dana zakat. Sebelum kelahiran UU Zakat, kecenderungan personal untuk membayar zakat kepersonal dipandang layak. Pasca UU ini telah diatur secara institusional pada Undang-Undang No. 38/1999 tentang Pengelolaan Zakat dan pengembangan menjadi Undang-Undang No. 23/ 2011 tentang pengelolaaan zakat secara institusional dilakukan oleh Badan Amil Zakat Nasional (BAZNAS) dan Lembaga Amil Zakat (LAZ), (Hamzah, 2016).

Sebagai instrument dengan target outcome tertentu, masih sedikit penerima zakat yang dapat mencapai posisi itu. Penelusuran diberbagai litelatur online tentang sukses zakat, hanya ditemukan dua fenomena menarik. Pertama, Kisah inspiratif sahabat warung: "Pak Imam dan Warungnya". Tersampaikan bahwa Pak Imam telah berhasil mengubah cara berfikir dalam pengelolaan bisnis warung setelah mendapat pelatihan tentang manajemen dan tambahan modal usaha yang dilaksanakan oleh LAZ Sukses. Kini usaha warung ini oleh LAZ Sukses nilainya telah besar, (Rozi, 2019). Kedua, informasi LAZ "Rumah Zakat Indonesia". LAZ ini telah melakukan kegiatan pembinaan sesam binaan dengan mengundang peserta binaan yang dipandang sukses untuk menjadi narasumber. Narasumber yang ditampilkan ada dua orang yaitu, Hartini dan Rohyatri yang dipandang sukses oleh LAZ dalam membangun usaha. Hartini dinilai telah berpenghasilan dua belas juta (Rp. 12.000.000) perbulan, (Rumah Zakat, 2019). Data Baznas tahun 2018 menyatakan bahwa LAZ Rumah Zakat berhasil mengubah 26 prosen mustahik dengan standard hisab emas dan 23 proses dengan standard hisab beras dari binaannya yang berawal mustahik (penerima zakat) menjadi muzakki (wajib zakat). Dalam hal peningkatan pendapatan mengalami peningkatan 97.88 prosen serta berhasil memperpendek usia pengentasan kemiskinan mustahik menjadi 3.68 tahun versi badan pusat statistic, (Republika, 2019). 
Implikasi yang ditimbulkan para penerima zakat, secara umum dipandang memliki relevansi dengan penerapan kepempimpinan transformatif. Sebagai penerima zakat, mereka memiliki tingkat kehidupan yang rendah dan pola pikir yang kurang produktif. Pemberian bantuan dan pendampingan yang dilaksanakan oleh institusi berpeluang mendorong peningkatan status bagi penerima dana zakat yang ada. Penelitian ini dipandang laik untuk dilakukan. Hal ini didasarkan pada: Pertama, ekonomi zakat dipandang sebagai disiplin ilmu baru yang merupakan pengembangan ilmu ekonomi Islam dan diperkirakan muncul sekitar tahun 2015, (Ekis, 2019). Dan telah mengembangkan ke kajian tentang perilaku penerima zakat dan wajib zakat. Kedua, amil zakat yang dikenal dengan badan amil zakat atau lembaga amil zakat memiliki peran yang sangat strategis dalam ekonomi zakat. Untuk mengingkatkan efektifitas pendayagunaan zakat, maka diperlukan kajian dari sisi kepemimpinan pengelola zakat. Pengembangan disiplin kepemimpinan transformatif ke dalam pengelolaan zakat dipandang sangat penting. Ketiga, kajian tentang pengelolaan zakat yang multi perspektif, dapat mendorong kekohan bangunan keilmuan ekonomi zakat. Olehnya pengelolaan zakat dapat dikembangkan secara ilmiah dan tataran praktis guna mendorong instrument zakat sebagai bagian dalam mengurangi kemiskinan. Disini, argumen kepemimpinan transformatif ekonomi zakat dapat didistribusi dalam mendorong penerima zakat menjadi wajib zakat melalui pendayagunaan zakat oleh amil.

\section{B. KAJIAN KEPUSTAKAAN}

Berdasarkan penelusuran terhadap litelatur ditemukan lima kajian yang dianggap relevan dengan topik ini. Pertama, Achmad Fatihuddin mahasiswa doctoral universitas Airlangga Surabaya melakukan penelitian tentang nelayan di Desa Srowo dengan menggunakan pendekatan fenomenalogis dikarenakan karena keterbatasan data tertulis, sehingga pendekatan ini dipandang tepat untuk melukiskan kondisi psikologis dengan realitas kehidupan mereka. Hasil penelitian menunjukkan bahwa karena keterbatasan ekonomi, mereka melakukan pilihan ekonomi ribawi namun pencerahan agama Islam, mereka melakukan transformasi dengan dengan tata cara yang Islami. Faktor internal yang mendorong bertransformasi adalah hasil nelayan tidak 
menentu dan kebutuhan keluarga semakin meningkat; sedang eksternal adalah pencerahan yang dilakukan terhadap mereka. Pilihan transformatifnya dalam bentuk ekonomi adalah mereka melakukan pembuatan krupuk karena ketersediaan bahan baku yang berasal dari hasil tangkapan. Hasil transformasinya adalah mereka menjalankan syariat Islam baik sebagai individu maupoun sebagai produsen. Sedang dampak ekonomi, adalah peningkatan kualitas ekonomi meningkat terukur dari tempat tinggal dan pendidikan dan keberagaman mereka, (Fatihuddin, 2019).

Kedua, Asep Saefuddin Jahar melakukan penelitian terhadap gerakan ekonomi Islam di Indonesia. Gerakana ekonomi yang diamatinya, dinilai sebagai suatu aktifitas transformativ yangmelahirkan perbedaan orientasi. Hasil penelitian menunjukkan bahwa pada awal kemerdekaan gerakan ekonomi Islam lebih berorientasi pada semangat nasionalisme dan keagamaan dengan melibatkan kelompok Islam dan ormas. Sementara pada erea reformasi tahun 1999-an lebih pada kesadaran sosial ekonomi dan pasar global yang sebagai reaksi atas kemiskinan dan ketertinggalam dalam pendidikan. Selain itu era ini menekankan pada gerakan kewiraswastaan untuk pengembangan masyarakat sehingga melahirkan gagasan mendirikan bank Islam dan lembaga filantropi Islam. Pada perkembangan lebih lanjut semangat keislaman melebur pada konteks demokratisasi sehingga aspek akuntabilitas dapat dikembangkan menjadi pemberdayaan pada masyarakat dan kesejahteraan, (Jahar, 2019).

Ketiga, Taufik Kurrahman menulis transformasi ekonomi Islam dalam sistem hukum perbankan nasional dan problematika kewenangan absolute peradilan agama. Pendekatan yuridis normatif empiris. Hasil penelitian menunjukkan bahwa transformasi ekonomi Islam telah tertransformasi ke hukum nasional telah dilakukan dengan baik dan terjadi ketidakpastian hukum dalam memberikan kewenangan absolut kepada pengadilan agama dalam menangani sengketa ekonomi, (Kurrohman, 2019).

Keempat, Pesantren Virtual mempublikasikan tulisan berjudul Hijrah dan Transformasi Ekonomi. Dalam tulisan tidak disebutkan siapa penulisnya. Tidak ditemukan konseptransformasi yang dimaksud oleh penulis, namjun jika dicermati tulisan melalui sub judul yang diajukan, maka ditemukan sub judul yang menyebut membangun 
ekonomi dan sub judul sistem ekonomi syariah. Dalam pandangannya penulis menyatakan bahwa "sekaranglah momentum yang tepat bagi bangsa Indonesia untuk berhijrah dari sistem ekonomi konvensional menuju sistem ekonomi syariah secara bertahap dan berharap", (Pesanternviritual, 2019). Atas pandangan ini dipahamibahwa transformasi adalah memilih system ekonomi syariah sebagai alternatif dan solusi dan meninggalkan ekonomi konvensional.

Kelima, Agus Syafii menulis dengan judul peran bank syariah dalam transformasi ekonomi di Indonesia. Dalam tulisan yang bersifat popular dia menguraikan peran bank syariah melalui pembiayaan usaha kecil dan mikro termasuk kehadiran lembaga perbankan dan lembaga non bank syariah seperti baitul mal wattanwil, (Syafi'i, 2019). Konsep transformasi yang dapat dipahami adalah memberikan ransangan ekonomi dan kebijkan melalui peran bank syariah dalam pengembangan ekonomi dan kesejahteraan, atau dengan tegas dinyatakan bahwa transformasi melahirkan kebijakan.

\section{METODE PENELITIAN}

Penelitian ini menggunakan metode studi kepustakaan atau library research. Dimana sumber data yang menjadi bahan kajian berupa buku, jurnal dan situs internet yang terkait dengan topik. Sumber data penelitian ini terdiri dari 8 buku, 4 jurnal dan 8 situs internet yang terkait dengan informasi trasformasi ekonomi zakat. Dari berbagai seumber tersebut, selanjutnya data-data relevan dikumpulkan menggunakan teknik dokumentasi. Teknik ini dapat mencari data mengenai hal-hal atau variabel yang berupa catatan, pandangan dan lainnya yang berkaitan dengan topic kajian (Arikunto, 2010). Instrumen penelitian digunakan dalam bentuk daftar check-list klasifikasi bahan penelitian, skema penulisan dan format catatan penelitian.

Terakhir, data dianalisis menggunakan metode analisis isi (Content Analysis). Dimana, analisis ini digunakan untuk mendapatkan inferensi yang valid dan dapat diteliti ulang berdasarkan konteksnya (Kripendoff, 1993). Dalam analisis ini dilakukan proses memilih, membandingkan, menggabungkan dan memilah berbagai pengertian hingga ditemukan informasi yang relevan dengan kajian. Untuk menjaga validitas proses kajian dan mencegah serta mengatasi mis - 
informasi (human error) penulis melakukan pengecekan antar pustaka (reference check).

\section{HASIL DAN PEMBAHASAN}

\section{Teori Transformasi Ekonomi Zakat}

a. Transformasi Ekonomi

Menko Perekonomian periode 2019-2014 Darwin Nasution memberikan gambaran mengenai transformasi "tidak perlu misalnya petani di desa pindah ke kota menjadi buruh, namun dengan transformasi ekonomi mereka tetap bertani dengan lebih efisien memanfaatkan infrastruktur yang memadai dan teknologi pertanian yang maju, serta kepastian adanya off taker yang akan membeli produk pertaniannya dengan harga yang baik", (Nasution, 2019). Saat ini, transformasi ekonomi yang digagas oleh pemerintah berfokus pada pemanfaatan potensi desa sebagai basis pertumbuhan ekonomi daerah. Dampaknya terjadinya peningkatan kualitas hidup masyarakat. Selanjutnya memberikan landasan atas lima dasar tarnasformasi. Kelima dasar yang dimaksud adalah optimalisasi pembangunan infrastruktur, penguatan implementasi kebijakan pemerataan ekonomi, minimalisasi ketergantungan terhadap modal asing jangka pendek, efisiensi pasar tenaga kerja dan peningkatan kualitas Sumber Daya Manusia (SDM), serta konfigurasi Investasi untuk mendukung pertumbuhan, (Nasution, 2019). Gagasan ini berkenaan upaya pemerintah untuk memanfaatkan potensi desa dalam rangka peningkatan pembangunan sosial ekonomi pedesaaan. Pandangan ini merumuskan dua hal: Pertama bahwa kebijakan pemerintah menghendaki agar potensi desa (PD) dikembangkan dengan optimal dalam memberi manfaat sebesar-besarnya bagi peningkatan kesejahteraan masyrakat desa. Kedua, potensi desa dalam hal ini Sumber Daya Manusia Pedesaaan (SDMP), diarahkan pada pembinaan sumber daya manusia perdesaan untuk mendorong keunggulan.

\section{b. Pemberdayaan Zakat}

Menurut Hamzah terdapat pola pemberdayaan yaitu pola tunggal dan pola terintegrasi, (Hamzah, 2015). Pola tunggal adalah menggunakan dana zakat untuk kepentingan mustahik. Sedangkan pola terintegrasi adalah menggabungkan dana zakat dan dana non zakat dalam suatu pembiayaan untuk melaksanakan kegiatan pemberdayaan kepada 
mustahik. Selanjutnya, dilihat dari sisi prosentase pendayagunaan, bahwa dana zakat dapat dialokasikan pengggunaannya sesuai kebijakan oleh amil zakat, (Hamzah, 2016). Pada penerima zakat terdapat beban yang harus diemban. Dengan kata lain penerima zakat tidak diberikan secara gratis dalam arti tanpa beban. Beban zakat yang menurut istilah yang digunakan adalah konpensasi fakir sebagai penerima zakat hasil guna minimal dalam memenuhi kebutuhan dasar. Sementara itu, hasil guna maksimal adalah menjadi muzakki. Fi Sabilillah, hasil guna minimal adalah menegakkan Islam, hasil guna maksimal adalah Islam tegak secara maksimal, (Hamzah, 2019).

\section{Pendayagunaan Zakat pada kepemimpinan transformatif}

Pengembangan potensi zakat dapat dilakukan dengan diversifikasi zakat. Istilah diversifikasi mengandung arti usaha untuk meningkatkan produksi dengan menambah jenis atau keanekaramaan hasil produksi, (Afika, 2019). Yaitu melakukan perluasan objek zakat. Menilik sejarah perzakatan, pada awalnya dikenal dua jenis zakat yaitu: zakat fitrah dan zakat harta (zakat maal). Zakat harta mengalami perkembangan sehingga dikenal istilah zakat profesi. Kehadiran zakat profesi secara substantive adalah upaya merespon sumber-sumber baru ekonomi masyarakat ada jamannya. Namun demikian, kehadiran zakat profesi ini tidak dapat dipandang telah mendorong pertumbuhan dana zakat. Dari berbagai informasi diketahui bahwa potensi dana zakat sangat besar dibanding dengan dana zakat yang dapat terealisir oleh amil zakat.

Zakat maal atau zakat harta yang kemudiaan diversifikasi ke zakat profesi, adalah menimbulkan bias dalam penerapannya. Zakat profesi yang memberikan sumber profesional, cenderung menggunakan uang sebagai instrument pembayaran zakat atau alat bayar zakat. Secara praksis dipahami bahwa profesi diberlakjukan bagi mereka yang menghasilkan pendapatan. Pendapat ini selalu benar karena, fakta terdapat profesi yang tidak menghasilkan uang sebagai hasil langsung atau tidak dari gaji dalam arti uang, tetapi berasal dari bagi hasil. Sebagai contoh, pengembala ternak. Profesi ini memperoleh bagian dari majikannya dengan mendapatkan hewan gembalaan dan tidak dengan uang. 
Penggunaan instrument uang, sebagai instrument transaksi antara wajib zakat dengan amil dan selanjutnya amil menyerahkan kepada penerima zakat. Pola ini dipandang tidak tepat, karena memperkecil gerakan media zakat. Pada beberapa daerah di Indonesia, media uang dapat efektif, namun pada daerah lainnya media ini tidak efektif, sebaliknya media non-uang dapat menjadi alternative solusi pada daerah tertentu dan pada daerah lainnya tidak menjadi solusi. Pada daerah perkotaan misalnya, yang memiliki basis perdagangan dan industri, maka sangat memungkinkan uang menjadi media transaksi. Karena pada umumnya sumber pencaharian masyarakat kota sesuai dengan basisinya.

\section{Pengembangan Amil sebagai kunci Kepemimpinan Transformatif}

Kepentingan pembahasan ini akan mengacu pada pandangan Schermerhor yang memberikan landasan mengenai kepemimpinan transformatif. Schermerhorn menyatakan bahwa kepemimpinan transformatif memiliki identitas yaitu: Visioner, Kharisma, memiliki simbolis, memperdayakan, Mengembankan Intelektual, Berintegritas, (Schermerhorn, 1996).

a. Visioner

Visioner adalah sebuah pandangan yang dikembangkan seseorang dengan memperhatikan perubahan-perubahan lingkungan guna merumuskan tujuan yang akan dicapai pada masa tertentu. Oleh Kaplan menyatakan bahwa ia berarti apa yang akan dikerjakan, (Kaplan dan Norton, 2004). Pemimpin yang memiliki visioner adalah ia mememiliki gagasan dan perasaan kejelasan yang akan dicapai; kemampuan mengkomunikasikan dengan pihak lain; memiliki kemampuan untuk mendorong pencapain visi, (Schermerhorn, 1996). Pada telaah bahasa Arab, terdapat dua terma yang secara sederhana mengandung arti pekerja, yaitu terma amil dan terma fail. Terma amil, menunjukkan pelaku dengan memperhatikan atas pengaruh yang ditimbulkan dari pekerjaan itu. Secara tegas dinyatakan bahwa ia bekerja dengan mempertiumbangkan ansur manajemen dan risiko dalam pekerjaan; sebaliknya fail yang mengandung arti juga bekerja cenderung tidak memperhatikan aspek manajemen dan risiko dalam melaksankaan suatu pekerjaan, (Hamzah, 2016). 
Term yang dipergunakan oleh Alquran berkaitan dengan zakat adalah amil dan bukan fail. Pemilihan tetma ini secara visioner amil dibebankan amanah untuk mengembangkan gagasan pengelolaan zakat yang berbasis manajemen dan risiko. Tipikal amil yang demikian itu, secara normatif pada pasal 3 huruf ( $a$ dan b) undangundang pengelolaan zakat menyebut pengelolaan zakat bertujuan untuk meningkatkan efektifitas dan efiisiensi pelayanan dalam pengelolaan zakat dan meningkatkan manfaat zakat untuk mewujudkan kesejahteraan masyarakat. Sementara badan amil zakat nasional (Baznas) memiliki visi menjadi pengelola zakat terbaik dan terpercaya dunia, (Baznas, 2019).

Memperhatikan makna terma amil dan visi Baznas, maka pertanyaan yang diajukan adalah apakah hal itu dapat dikatakan memiliki relevansi visioner. Jawaban pertanyaan ini adalah dinyatakan memiliki visoner. Pertama, berbasis manajemen dan berbasisi risiko. Sebagai keuangan Islam, zakat tidak dikelola dengan kata "sekedar" tetapi didorong untuk mengembangkan prinsip-prinsip manajemen dan capaiakn kinerja yang harus terukur. Pengelolaan zakat yang dilakukan dengan "serampangan" dalam arti tidak berbasis manajemen dipandang keluiar dari makna dasar amil yakni hanya sebagai fail. Kedua, Berbasis Risiko. Terdapat pengertian yang dikemukakan oleh Bramantyo Djohanputro bahwa risiko adalah "penyebaran atau penyimpangan dari target, sasaran, atau harapan", (Djohanputro, 2006). Lebih lanjut Bramantyo mencotohkan dengan "mengharapkan harga saham tahun depan Rp. 1500 perlembar, ada kemungkinan harga saham akan naik mencapai Rp. 2.000 per lembar dan kemungkinan turun sampai Rp, 800, per lembar, maka fluktuasi tersebut juga menunjukkan adanya risiko, (Djohanputro, 2006). "Risiko adalah suatu kejadian yang tidak menyenangkan, dan berdampak pada penurunan mashlahah yang diterima", (P3EI, 2008).

Memperhatikan contoh risiko dari sisi pengelolaan keungan, maka diketahui bahwa modal financial merupakan koridor yang merupakan titik star dalam menetapkan harapan dan risiko kerugian. Harapan merupakan titik yang berada di atas modal financial sedangkan risiko kerugian adalah titik yang harus diletakkan selaras dengan titik koridor. Pengelolaan zakat sebagai 
keuangan Islam, kiranya mengacu pada sisi resiko, terlebih lagi jika dikaitkan pada uraian sebelumnya bahwa zakat memiliki kompensasi bagi konpensasi bagi penerimanya.

\section{Tabel 1. tentang Sintesis dan Implikasi Kepempinan dari Unsur Visoner dengan makna Amil Pada Pengelolaan Zakat}

\begin{tabular}{|c|c|c|c|c|}
\hline No. & Visoner & Amil & Sintesis & $\begin{array}{l}\text { Implikasi } \\
\text { Kepemimpinan }\end{array}$ \\
\hline 1 & Ide Besar & $\begin{array}{l}\text { Manajenem } \\
\text { dan Berbasis } \\
\text { Risiko }\end{array}$ & $\begin{array}{lr}\text { Ide besar } & \text { yang } \\
\text { dilandasi } & \\
\text { manajemen } & \text { dan } \\
\text { risiko } & \text { untuk } \\
\text { mendorong } & \\
\text { perubahan } & \text { sosial } \\
\text { ekonomi pada } \\
\text { penerima zakat }\end{array}$ & 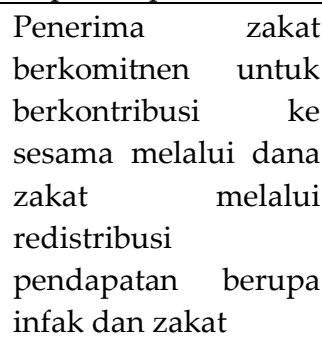 \\
\hline 2 & $\begin{array}{l}\text { Kemampuan } \\
\text { mengkomuni } \\
\text { kasikan }\end{array}$ & $\begin{array}{l}\text { Zakat berbeda } \\
\text { dengan } \\
\text { instrument } \\
\text { keuangan lain }\end{array}$ & $\begin{array}{l}\text { Penguatan Etos } \\
\text { kemandirian } \\
\text { Penerima zakat }\end{array}$ & $\begin{array}{l}\text { Penerima zakat } \\
\text { menjadi pelopor } \\
\text { dalam } \\
\text { mempromosikan } \\
\text { perbedaan zakat } \\
\text { dengan instrument } \\
\text { ekonomi lainnya }\end{array}$ \\
\hline 3 & $\begin{array}{l}\text { Kemampuan } \\
\text { mendorong } \\
\text { pencapaian } \\
\text { visi }\end{array}$ & \begin{tabular}{lr}
\multicolumn{2}{l}{ Zakat } \\
beban & resikiko \\
yang & harus \\
dikelola &
\end{tabular} & $\begin{array}{l}\text { Mendorong } \\
\text { penerima zakat } \\
\text { untuk berkinerja } \\
\text { mencapai } \\
\text { kemandirian }\end{array}$ & $\begin{array}{lr}\text { Penerima } & \text { zakat } \\
\text { memiliki pengalaman } \\
\text { dalam penguatan } \\
\text { jaringan }\end{array}$ \\
\hline
\end{tabular}

Tabel di atas memperlihatkan unsur sintesisi sebagai penggabungan dari aspek visioner dengan amil zakat. Pada pernyataan pada unsur sinkronisasi, akan terjabarkan melalui unsur implikasi kepemimpinan. Unsur implikasi kepemnimpinan dimaksudkan sebagai akibat dari kepemimpinan transformatif amil zakat kepada penerima zakat.

b. Kharisma

Kharisma adalah menimbulkan antusias orang lain, kepercayaan, loyalitas, kebanggaan, dan membangkitkan kepercayaan terhadapnya sebagai referensi pribadi secara emosional, (Schermerhorn, 1996). Kekuasaan kharismatik yang didapatkan atas 
pengabdian diri atas kesucian, sifat kepahlawanan atau yang patut dicontoh dari ketertiban atas kekuasaannya, (Muarib, 2019). Dari kedua pandangan ini dapat dirumuskan unsur kharisma meliputi sangat dipercaya, menjadi panutan; memiliki ide aktual dan strategis.

Tabel 2. Sintesis dan implikasi kepemimpinan dari unsur amil dan kharisma

\begin{tabular}{|c|c|c|c|c|}
\hline No. & Kharisma & Amil & Sintesis & $\begin{array}{l}\text { Implikasi } \\
\text { Kepemimpinan }\end{array}$ \\
\hline 1 & $\begin{array}{l}\text { Sangat } \\
\text { dipercaya }\end{array}$ & $\begin{array}{l}\text { Menjaga dana } \\
\text { zakat sebagai } \\
\text { dana syariat dan } \\
\text { dan umat }\end{array}$ & $\begin{array}{l}\text { Amil mendorong } \\
\text { penerima zakat } \\
\text { memanfaatkan } \\
\text { seoptimal } \\
\text { mungkin dana } \\
\text { zakat }\end{array}$ & $\begin{array}{l}\text { Mendorong etos } \\
\text { kerja penerima } \\
\text { zakat }\end{array}$ \\
\hline 2 & Panutan & $\begin{array}{l}\text { Sangat cermat } \\
\text { pada } \\
\text { pengelolaan } \\
\text { dana }\end{array}$ & $\begin{array}{l}\text { Penerima zakat } \\
\text { sangat cermat } \\
\text { dalam } \\
\text { penggunaan } \\
\text { dana zakat }\end{array}$ & \begin{tabular}{l}
\multicolumn{2}{l}{ Mendorong } \\
tingkat kehati- \\
hatian penerima \\
zakat dalam \\
pengelolaan dana \\
zakat
\end{tabular} \\
\hline 3 & $\begin{array}{ll}\text { Memiliki } & \text { Ide } \\
\text { Aktual } & \end{array}$ & $\begin{array}{l}\text { Responshif } \\
\text { terhadap } \\
\text { kebutuhan } \\
\text { penerima zakat }\end{array}$ & $\begin{array}{l}\text { Amil } \\
\text { mengalokasikan } \\
\text { secara rasional } \\
\text { pada kebutuhan } \\
\text { penerima zakat }\end{array}$ & $\begin{array}{ll}\text { Mendorong } & \\
\text { penerima zakat } & \text { zerfikir kritis, } \\
\text { tidak apatis } & \end{array}$ \\
\hline 4 & $\begin{array}{l}\text { Pemikiran } \\
\text { Strategis }\end{array}$ & $\begin{array}{l}\text { Optimalisasi } \\
\text { dana zakat }\end{array}$ & $\begin{array}{l}\text { Amil melakukan } \\
\text { pendampingan } \\
\text { penerima zakat }\end{array}$ & $\begin{array}{l}\text { Penerima zakat } \\
\text { mempeoleh } \\
\text { bimbingan } \\
\text { wawasan } \\
\text { manajemen dan } \\
\text { pengayoman } \\
\text { secara psikologis }\end{array}$ \\
\hline
\end{tabular}

c. Kekuatan Simbolik

Identias perjuangan, pemberian penghargaan, mendorong secara spontan dan terencana pemberian penghargaan karena prestasi tertinggi. 
Tabel 3. tentang Sintesis dan Implikasi kepemimpinan dari unsur kekuatan simbolik dan unsur amil

\begin{tabular}{|c|c|c|c|c|}
\hline No & $\begin{array}{l}\text { Kekuatan } \\
\text { Simbolik }\end{array}$ & Amil & Sintesis & $\begin{array}{l}\text { Implikasi } \\
\text { Kepemimpinan }\end{array}$ \\
\hline 1 & $\begin{array}{l}\text { Identitas } \\
\text { Perjuangan }\end{array}$ & $\begin{array}{l}\text { Amil sebagai } \\
\text { simbol agama dan } \\
\text { kesejahteraan } \\
\text { umat }\end{array}$ & $\begin{array}{l}\text { Pengelola zakat } \\
\text { yang berintegritas } \\
\text { dan profesional }\end{array}$ & $\begin{array}{l}\text { Mendorong } \\
\text { penerima zakat } \\
\text { bertanggungjawab } \\
\text { dan mandiri }\end{array}$ \\
\hline 2 & $\begin{array}{l}\text { Pemberian } \\
\text { Penghargaan }\end{array}$ & $\begin{array}{l}\text { Mendorong etos } \\
\text { kerja dan etos } \\
\text { ibadah serta sosial }\end{array}$ & $\begin{array}{lr}\text { Menghargai } & \text { kerja } \\
\text { keras } & \text { dan } \\
\text { kemandirian } & \end{array}$ & $\begin{array}{l}\text { Mendorong } \\
\text { penerima zakat } \\
\text { menghargai usaha } \\
\text { dan kerja sebagai } \\
\text { usaha kemandirian }\end{array}$ \\
\hline 3 & $\begin{array}{l}\text { Mendorong } \\
\text { Prestasi Tinggi }\end{array}$ & $\begin{array}{l}\text { Menghargai } \\
\text { dampak } \\
\text { pengelolaan zakat }\end{array}$ & $\begin{array}{l}\text { Menghargai } \\
\text { perubahan pola } \\
\text { pikir perilaku serta } \\
\text { sikap penerima } \\
\text { zakat }\end{array}$ & $\begin{array}{l}\text { Mendorong } \\
\text { penerima } \\
\text { menghargai } \text { zakat } \\
\text { bertahap }\end{array}$ \\
\hline
\end{tabular}

d. Memberdayakan

Membantu melakukan pengembangan; mengangkat dari penghambat kepercayaan diri; bertanggungjawab bersama; pemberian kesempatan dalam bekerja. Pendistribusian zakat selama ini dipandang kurang mendidik umat, (Tanjung, 2018).

Tabel 4. tentang Sintesis dan Implikasi kepemimpinan dari unsur Memberdayakan dan unsur amil

\begin{tabular}{|c|c|c|c|c|}
\hline No & Memberdayakan & Amil & Sintesis & $\begin{array}{l}\text { Implikasi } \\
\text { Kepemimpinan }\end{array}$ \\
\hline 1 & $\begin{array}{l}\text { Melakukan } \\
\text { Pengembangan }\end{array}$ & $\begin{array}{l}\text { Melakukan } \\
\text { peningkatan } \\
\text { status penerima } \\
\text { zakat }\end{array}$ & $\begin{array}{l}\text { Merancang } \\
\text { program } \\
\text { pengembangan } \\
\text { bagi penerima } \\
\text { zakat }\end{array}$ & $\begin{array}{l}\text { Penerima zakat } \\
\text { mampu } \\
\text { meningkatkan } \\
\text { ketahanan ekonomi } \\
\text { dan ekspansi }\end{array}$ \\
\hline 2 & $\begin{array}{l}\text { Mengangkat dari } \\
\text { penghambat } \\
\text { Kepercayaan Diri }\end{array}$ & $\begin{array}{l}\text { Mendorong rasa } \\
\text { percaya diri } \\
\text { penerima zakat }\end{array}$ & $\begin{array}{l}\text { Melakukan } \\
\text { program } \\
\text { peningkatan } \\
\text { kepercayaaan } \\
\text { diri }\end{array}$ & $\begin{array}{l}\text { Penguatan } \\
\text { komptensi diri } \\
\text { penerima zakat } \\
\text { dengan berbagai } \\
\text { program } \\
\text { pemberdayaan }\end{array}$ \\
\hline
\end{tabular}

$12 \mid$ WRANSIB ZAKAT

Hamzah \& St. Umrah 


\begin{tabular}{|c|c|c|c|c|}
\hline No & Memberdayakan & Amil & Sintesis & $\begin{array}{l}\text { Implikasi } \\
\text { Kepemimpinan }\end{array}$ \\
\hline 3 & $\begin{array}{l}\text { Bertanggungjawa } \\
\text { b Bersama }\end{array}$ & $\begin{array}{l}\text { Membentuk } \\
\text { tanggungjawab } \\
\text { sosial umat } \\
\text { penerima zakat } \\
\text { sebagai bagian } \\
\text { umat Islam } \\
\end{array}$ & $\begin{array}{l}\text { Membuat } \\
\text { program yang } \\
\text { membangkitkan } \\
\text { tanggungjawab } \\
\text { sebagai mahluk } \\
\text { sosial }\end{array}$ & $\begin{array}{l}\text { Mendorong } \\
\text { penerima zakat } \\
\text { berfikir kritis, tidak } \\
\text { apatis dan optimal } \\
\text { dalam mengelola } \\
\text { zakat yang diterima }\end{array}$ \\
\hline 4 & $\begin{array}{l}\text { Pemberian } \\
\text { Kesempatan } \\
\text { Bekerja }\end{array}$ & $\begin{array}{l}\text { Memberikan } \\
\text { modal untuk } \\
\text { pembenahan } \\
\text { internal }\end{array}$ & $\begin{array}{l}\text { Merancang } \\
\text { program } \\
\text { penyiapan pra } \\
\text { kerja penerima } \\
\text { zakat }\end{array}$ & $\begin{array}{l}\text { Penerima Zakat } \\
\text { mempeoleh } \\
\text { bimbingan } \\
\text { wawasan } \\
\text { berwirausaha dan } \\
\text { ketahanan ekonomi } \\
\text { keluarga }\end{array}$ \\
\hline
\end{tabular}

e. Pengembagan Intekektual

Memperoleh keuntungan atau menambah keterlibatan orang lain dalam mendorong kesadaran pemecahan masalah yang menggemparkan melalui kreasi dalam pemecahan masalah tingkat tinggi. Secara rinci dapat dinilai mencakup: Kemampuan merumuskan pemecahan masalah; kemampuan komunikasi pada orang lain.

Tabel 5. tentang Sintesis dan Implikasi Kepemimpinan dari unsur Pengembangan Intelektual dan unsur Amil

\begin{tabular}{|c|c|c|c|c|}
\hline No & $\begin{array}{l}\text { Pengembangan } \\
\text { Intelektual }\end{array}$ & Amil & Sintesis & $\begin{array}{l}\text { Implikasi } \\
\text { Kepemimpinan }\end{array}$ \\
\hline 1 & $\begin{array}{l}\text { Kemampuan } \\
\text { Memahami } \\
\text { Masalah }\end{array}$ & $\begin{array}{l}\text { Sensitif dan } \\
\text { rekatif dalam } \\
\text { melihat } \\
\text { problematika }\end{array}$ & $\begin{array}{l}\text { Melakukan kajian } \\
\text { ilmiah dalam } \\
\text { melihat fenomena } \\
\text { aktual }\end{array}$ & $\begin{array}{l}\text { Pemenuhan } \\
\text { kebutuhan dan } \\
\text { distribusi penerima } \\
\text { zakat menjadi } \\
\text { akurat }\end{array}$ \\
\hline 2 & $\begin{array}{l}\text { Kemampuan } \\
\text { Berkomunikasi }\end{array}$ & $\begin{array}{l}\text { Zakat berbeda } \\
\text { dengan } \\
\text { instrument } \\
\text { keuangan lain }\end{array}$ & $\begin{array}{l}\text { Penguatan Etos } \\
\text { kemandirian } \\
\text { Penerima zakat }\end{array}$ & $\begin{array}{l}\text { Penerima zakat } \\
\text { menjadi pelopor } \\
\text { dalam } \\
\text { mempromosikan } \\
\text { perbedaan zakat } \\
\text { dengan instrument } \\
\text { ekonomi lainnya }\end{array}$ \\
\hline
\end{tabular}


f. Berintegritas

Berintegritas mengandung arti kejujuran dan dipercaya, teguh dalam pendirian, melaksanakan komitemen pertemuan.

Tabel 6. tentang Sintesis dan Implikasi Kepemimpinan dari unsur Berintegritas dan unsur Amil

\begin{tabular}{|c|c|c|c|c|}
\hline No & Berintegritas & Amil & Sintesis & $\begin{array}{l}\text { Implikasi } \\
\text { Kepemimpinan }\end{array}$ \\
\hline \multirow[t]{2}{*}{1} & \multirow[t]{2}{*}{ Bersikap Jujur } & Dasar & Modal dasar & Mendorong \\
\hline & & Amil & kepemimpinan & $\begin{array}{l}\text { Penerima } \\
\text { memiliki } \\
\text { sosial }\end{array}$ \\
\hline \multirow[t]{2}{*}{2} & \multirow[t]{2}{*}{ Dapat Dipercaya } & \multirow{2}{*}{$\begin{array}{l}\text { Pemegang } \\
\text { Amanah }\end{array}$} & Melaksanakan & Mendorong \\
\hline & & & $\begin{array}{l}\text { program sesuai } \\
\text { prosedural }\end{array}$ & $\begin{array}{l}\text { penerima zakat } \\
\text { taat aturan }\end{array}$ \\
\hline \multirow[t]{2}{*}{3} & Teguh & Konsisten & Kesinambungan & Penerima zakat \\
\hline & Pendirian & $\begin{array}{l}\text { dalam Aturan } \\
\text { Syariy } \\
\text { mengelola zakat } \\
\end{array}$ & Program & $\begin{array}{l}\text { terbina secara } \\
\text { berkesinambunga } \\
\mathrm{n}\end{array}$ \\
\hline 4 & $\begin{array}{l}\text { Melaksanakan } \\
\text { Komitemen }\end{array}$ & $\begin{array}{l}\text { Program kerja } \\
\text { terumuskan }\end{array}$ & $\begin{array}{ll}\text { Fokus } & \text { pada } \\
\text { pelaksanaan } & \end{array}$ & $\begin{array}{l}\text { Mendorong } \\
\text { penerima zakat }\end{array}$ \\
\hline & Pertemuan & $\begin{array}{l}\text { untuk } \\
\text { dilaksanakan }\end{array}$ & program & $\begin{array}{lr}\text { berkeja } & \text { secara } \\
\text { cermat } & \text { dan } \\
\text { terencana } & \end{array}$ \\
\hline
\end{tabular}

\section{E. KESIMPULAN}

Pendayagunaan zakat pada kepemimpinan transformative, lebih melihat pada kemampuan amil dalam memberdayakan penerima zakat. Trasfer of knowledge amil kepada penerima zakat menjadi parameter utama dalam melihat fenomena penguatan masyarakat. Semakin berdaya penerima zakat, semakin baik kepmemimpinan traformatifnya. Pandangan Schermerhor terkait pengembangan kepemimpinan ideal dinataranya memiliki kharisma, simbolis, memperdayakan, intelektual dan berintegritas menjadi relevan digunakan dalam pengembangan amil sebagai kunci kepemimpinan transformative. Dimana, gagasan ini dapat memberikan akses pemberdayaan yang optimal guna mentrasformasikan penerima zakat menjadi wajib zakat. 


\section{F. UCAPAN TERIMA KASIH}

Penulis mengucapkan terimaksih kepada Fakultas Ekonomi dan Bisnis Islam (FEBI) UIN Alauddin Makassar dan Pengelola Perpustakaan STAIN Sorong dalam memberikan bantuan teknis atas penyelesaian penelitian ini. Selanjutnya, disampaikan juga terimaksih kepada para kolega khususnya Dosen Ilmu Ekonomi Syariah yang banyak memberikan masukan dan informasi berarti dalam menambah bahan referensi pada kajian ini.

\section{DAFTAR PUSTAKA}

Agus, A. S. (2019). Peran Bank Syariah dalam Transformasi Ekonomi di Indonesia. http://kompasiana.com, September 2019.

Arikunto. (2010). Prosedur Penelitian Suatu Pendekatan Praktik. Jakarta: Rineka Cipta.

Djohanputro, B. (2006). Manajemen Risiko Korporat Terintegrasi. Jakarta: PPM.

Ekis. (2019). Ekonomi Zakat Dan Wakaf Pada Sejumlah Konsentrasi S3. https//ekis.pas.ugm.ac.id, September 2019.

Fatihuddin, A. (2019). Transformasi Ekonomi Islam: Dari Nelayan Tradisional menkadi Industri Krupuk. UNAIR Surabaya, 2015. http://repository unair.ac.id, September 2019.

Hamzah. (2016). Keuangan Sosial dan Bisnis Islam. Yogyakarta: Kaukaba. . (2015). Ekonomi Zakat. Makassar: Alauddin Press. . (2015). Kompensasi Pada Penerima Zakat Perspektif Ekonomi Islam. Jurnal El-Qisth, 5(2).

Hafidhuddin, M. D. (2002). Zakat Dalam Perekonominan Moderen. Jakarta: Gema Insani Press.

Jahar, A. S. (2019). Transformasi Gerakan Ekonomi Kontemporer. Jurnal MIQOT, 2(2).

Kaplan, R. \& Norton, D. P. (200)4. Strategi Maps. Boston: Harvard Business School Publishing Corporation.

Krippendoff, K. (1993). Analisis Isi: Pengantar Teori dan Metodologi. Jakarta: Citra Niaga Rajawali Press.

Kurrohman, T. (2019). Transformasi Ekonomi Islam Dalam Sistem Hukum Perbankan Nasional Dan Problematika Kewenangan Absolute Peradilan Agama. https://openjournal.umpan.ac.id, September 2019. 
Miles, M.B., et al. (1994). Qualitative Data Analysis: An Expanded Sourcebook (SAGE Publications).

Muarib, M. (2019). Pengertian Kepemimpinan Kharismatik. http://mufidmuarib17.wordpresss.com, Januari 2020.

Nasution, D. (2019). Soal Tranformasi Ekonomi; Darwin: Petani Tak Perlu Petani Jadi Buruh. https://financedetik.com, September 2019.

Pesanternviritual. (2019). Hijrah dan Transformasi Ekonomi, dalam Pesantren Virtual. http://pesantrenvirtual.com, September 2019.

Schermerhorn, J. R. (1996). Management, USA: John Wiley \& Sons.Inc.

Tanjung, M. A. et al. (2018). Arus Baru Ekonomi Indonesia. Jakarta: Flashmediatama.

Republika. (2019). Enam Pencapaian Sukses Baznas. https//khazanah.republika.co.id, September 2019.

Rumah Zakat. (2019). Berbagi Cerita Sukses Dengan Mitra Binaan. https//rumahzakat.org, September 2019.

Rozi, M. F. (2019). Kisah Inspiratif Sahabat Warung: "Pak Imam dan Warungnya". https//zakatsukses.org, September 2019.

Tim Pusat Pengkajian dan Pengembangan Ekonomi Islam (P3EI). (2008). Ekonomi Islam. Jakarta: Rajawali. 